\title{
PERMOHONAN KELUAR ISLAM: KAJIAN KES DI MAHKAMAH TINGGI SYARIAH NEGERI SABAH
}

\author{
Application to Leave Islam: \\ A Case Study in Sabah Shariah High Court
}

\author{
Pg Ismail Pg Musa ${ }^{1}$ \\ Siti Zubaidah Ismail ${ }^{2}$
}

\begin{abstract}
In 2010, the Shariah Courts in Sabah have reportedly received 238 applications to leave Islam, the largest number in Malaysia. Out of this number, 67 applications have been approved. This has given rise to the question as to why these applications were done and how they were dealt with by the Shariah Courts in Sabah. The main objective of this article is to study how the Shariah Courts in Sabah handled those cases, by examining case files at two High Courts in Kota Kinabalu and Keningau. To achieve this objective, semi-structured interviews and observations were also conducted. Throughout the analysis, it is found that the majority of cases were identified as cases to certify the applicants,
\end{abstract}

\footnotetext{
1 Master Candidate, Department of Shariah and Law, Academy of Islamic Studies, University of Malaya \& Shariah Prosecutor, Department of Islamic Religious Sabah, Kota Kinabalu, pgismailpgmusa@gmail.com

2 Senior Lecturer, Department of Shariah and Law, Academy of Islamic Studies, Universiy of Malaya, szubaida@um.edu.my
} 
religious status rather than application to convert out of Islam. This study also found that applications to convert out of Islam were also filed by non-Muslims and also by those whose religious status have not been determined due to mixed marriages between Muslim and non-Muslim. Apart from that, there were also cases filed by those who professed Islam in mass ceremonies in the 1970s until 1980s. Although this finding shows that the issue regarding apostasy in Sabah is not rampant, the Shariah Courts nevertheless, are required to adjudicate the cases. In the final part of this article, the writers give some recommendations regarding management approach and statutory amendment in order to improve the management of such cases in the Shariah Courts of Sabah.

Keywords: application to leave Islam, apostasy, Shariah Court of Sabah, Sabah Native Court, Muslim and non-Muslim marriage

\section{PENDAHULUAN}

Beberapa tahun yang lalu, Menteri di Jabatan Perdana Menteri, Yang Berhormat Datuk Seri Jamil Khir Bahrom ketika pembentangan di Parlimen telah menyatakan bahawa bagi tempoh 2000 hingga 2010, terdapat 686 permohonan keluar Islam telah dikemukakan di Mahkamah Syariah seluruh negara. ${ }^{3}$ Dari jumlah itu, sebanyak 135 permohonan telah dibenarkan oleh Mahkamah Syariah. Mahkamah Syariah di Sabah mencatatkan jumlah tertinggi permohonan iaitu sebanyak 238 kes dan 67 daripadanya telah diluluskan. Sepintas lalu, kenyataan ini menunjukkan bahawa Mahkamah Syariah Sabah telah meluluskan banyak permohonan orang Islam untuk keluar dari agama Islam. Ini telah menimbulkan persoalan kepada umum, apakah undang-undang yang digunakan oleh Mahkamah Syariah dalam membenarkan 135 permohonan untuk keluar Islam tersebut di Sabah kerana Islam melarang perbuatan keluar Islam atau murtad. Namun, selepas itu, Menteri berkenaan tampil menjelaskan bahawa tidak ada satupun kes yang diluluskan tersebut adalah kes keluar Islam atau murtad. Sebaliknya, semua 135 kes yang telah diluluskan tersebut telah diputuskan atas merit pengesahan status agama atau pengesahan bukan Islam yang mana pemelukan Islam pihak-pihak berkenaan didapati oleh Mahkamah

3 MalaysiaKini, 'Jamil Khir: Permohonan Murtad 135 Orang Diluluskan,' laman sesawang MalaysiaKini, http://www.malaysiakini.com.news/166920, 14 Jun 2011. 
Syariah sebagai tidak sah. ${ }^{4}$ Oleh sebab itu, tidak timbullah isu keluar Islam kerana permohonan tersebut difailkan oleh orang yang masih belum ditentukan pemelukan Islamnya sah atau sebaliknya. Pernyataan ini telah menimbulkan satu lagi persoalan lain, iaitu apakah hanya golongan mualaf sahaja yang memfailkan permohonan keluar Islam di Mahkamah Syariah?

Sekiranya diteliti laporan kes permohonan keluar Islam di dalam jurnal undang-undang sama ada di Mahkamah Sivil ataupun di Mahkamah Syariah, kebanyakannya difailkan oleh golongan mualaf ${ }^{5}$ dan juga orang Islam yang tidak pernah dididik dan dibesarkan mengikut agama Islam. ${ }^{6}$ Antara faktor yang menyebabkan golongan ini membuat permohonan keluar Islam di Mahkamah Syariah adalah kerana kecewa dengan kehancuran rumahtangga mereka, ${ }^{7}$ tiada bimbingan mengenai ajaran Islam, ${ }^{8}$ tiada tempat bergantung setelah memeluk Islam ${ }^{9}$ dan juga ingin berkahwin dengan orang bukan Islam. ${ }^{10}$ Ini menunjukkan permohonan keluar Islam juga turut difailkan oleh Orang Islam secara keturunan. Oleh kerana itu, golongan mualaf bukanlah satusatunya golongan yang telah memfailkan permohonan tersebut di Mahkamah Syariah.

"Kekeliruan" laporan tersebut berlaku rentetan perolehan maklumat yang tidak tepat yang dijana melalui Sistem Pendaftaran Kes Mahkamah Syariah

4 MalaysiaKini, 'Menteri: 135 Bukan Murtad Tapi Tak Sah Masuk Islam,' laman sesawang MalaysiaKini, http://www.malaysiakini.com.news/167055, 15 Jun 2011; MalaysiaKini, 'Bilangan Murtad: Mana Satu yang Betul?' laman sesawang MalaysiaKini, http://www.malaysiakini.com.news/167078. 16 Jun 2011.

5 Sia Kwee Hin lwn. JAIWP [1992] 2 CLJ, 1-4; Lim Yoke Khoon lwn. Pendaftar Muallaf, Majlis Agama Islam Selangor \& Yang Lain [2006] 4 CLJ, 513-526; Majlis Agama Islam Pulau Pinang lwn. Siti Fatimah Tan binti Abdullah [1430H] JH 27/2; Sumanthi a/p maniam lwn. Majlis Agama Islam Wilayah Persekutuan (1434H) JH36/1, 143-159.

6 Zubeydah Shaik Mohd lwn. Kalaichelvan Alagapan \& Yang Lain [2003] 8 CLJ, 840-848; Roslinda binti Pius lwn. Pendaftar Muallaf, Jabatan Hal Ehwal Agama Islam Negeri Sabah [2009] 1 CLJ (Sya), 485-494, Lina Joy lwn. Majlis Agama Islam Wilayah Persekutuan \& Yang Lain [2005] 4 CLJ.

7 Mohd Ridhuan Tee Abdullah, Cabaran Saudara Baharu di Malaysia (Kuala Lumpur: Utusan Publication \& Distributor Sdn. Bhd., 2012), 38; Ann Wang Seng, Murtad Jangan Pandang Sebelah Mata (Kuala Lumpur: Mustread Sdn. Bhd., 2009), 127.

8 Mohd Ridhuan Tee Abdullah, Cabaran Saudara Baharu di Malaysia, 39.

9 Ann Wan Seng, Murtad Jangan Pandang Sebelah Mata, 126.

10 Ann Wan Seng, Murtad Jangan Pandang Sebelah Mata, 45-56. Antara kes yang dibincangkan dalam buku berkenaan ialah Aisyah Bukhari, Hartina Kamaruddin, Norfazillah Abd Aziz dan Siti Salmah Mohd Yaasin. 
(SPKMS). SPKMS adalah portal pendaftaran kes di Mahkamah Syariah yang digunapakai oleh semua Mahkamah Syariah di Malaysia. Dalam konteks Sabah, Arahan Amalan Mahkamah Syariah Negeri Sabah No. 1 Tahun 2000 menghendaki semua kes yang didaftarkan di Mahkamah Syariah diberikan kod. Kod ini bertujuan untuk memudahkan pengenalan kes-kes tersebut di Mahkamah, memudahkan penyediaan penyataan perangkaan dan memudahkan Mahkamah menetapkan mod perbicaraan. Bagi kes permohonan keluar Islam dan juga pengesahan status agama akan didaftarkan di dalam SPKMS di bawah kod 043 yang bertajuk 'Permohonan Keluar Islam' yang telah menyebabkan semua kes yang didaftarkan di bawah kod tersebut akan dikenali sebagai permohonan keluar Islam. Justeru, istilah yang digunapakai dalam penulisan ini iaitu 'Permohonan Keluar Islam' adalah selaras dengan kod SPKMS tersebut.

Negeri Sabah dipilih sebagai fokus kajian ini kerana selain daripada dilaporkan sebagai negeri tertinggi menerima dan meluluskan permohonan keluar Islam di Malaysia, profil kesnya juga unik berbanding dengan kes yang pernah dilaporkan di negeri lain. Misalnya, dalam kes Permohonan Perisytiharan Status Agama Janisah bintiAbdRahim @Bigul di Mahkamah Tinggi Syariah Keningau, ${ }^{11}$ menunjukkan bahawa permohonan tersebut adalah untuk meminda status agama dalam MyKad kerana berlaku kesilapan di Jabatan Pendaftaran Negara (JPN). Ini menunjukkan kes permohonan keluar Islam yang difailkan di Mahkamah Syariah khususnya di Sabah juga difailkan oleh orang bukan Islam.

\section{SEPINTAS LALU MENGENAI UNDANG-UNDANG DAN PENTADBIRAN PERMOHONAN KELUAR ISLAM DI MALAYSIA}

Usaha untuk mewujudkan undang-undang berkenaan sudah pun bermula sejak akhir tahun 1990-an lagi, namun sehingga ke hari ini draf "Akta Pemulihan Akidah" masih dalam kajian. ${ }^{2}$ Masalah ini berhubung kait dengan nilai sensitiviti isu ini dalam kalangan orang Islam ataupun bukan Islam. Bagi pendokong hak asasi manusia, mereka berpandangan undang-undang tersebut boleh menjejaskan hak kebebasan beragama di Malaysia ${ }^{13}$ dan akan menjadikan

11 Kes Permohonan Perisytiharan Status Agama Janisah binti Abd Rahim@Bigul JH XXII (1427) H. 67-69.

12 Salleh Buang, Siri Perkembangan Undang-Undang di Malaysia, Perlembagaan dan Pentadbiran, Isu Kritikal, Jil. 2, (Kuala Lumpur: Dewan Bahasa \& Pustaka, 2007), 11-13.

13 Shad Saleem Faruqi, Document of Destiny, the Constitution of the Federation of Malaysia (Petaling Jaya: STAR Publication, 2008), 333-335. 
taraf Mahkamah Syariah setaraf dengan Mahkamah Sivil dalam memutuskan isu-isu Perlembagaan. Di peringkat negeri pula, undang-undang pemulihan akidah dibantah oleh Exco yang beragama Islam dan juga bukan Islam. Sebagai contoh di Selangor, Rang Undang-Undang Pemulihan Akidah 2000 telah dibantah wakil dari Gerakan dan MCA. ${ }^{14}$ Manakala di Perlis pula, Enakmen Perlindungan Akidah Perlis walaupun diluluskan oleh Dewan Undang Negeri, namun telah dibantah tiga Ahli Dewan dari PAS kerana Enakmen tersebut tidak memenuhi kehendak hukum syarak dan disifatkan mereka hanya sebagai 'gincu bibir' sahaja. ${ }^{15}$ Manakala peruntukan di negeri-negeri lain agak tidak selaras dan lebih malang lagi, terdapat negeri yang tiada sebarang peruntukan untuk menangani permasalahan keluar agama ini.

Oleh sebab itulah sehingga ke hari ini, belum ada satu undang-undang khusus berkenaan dengan permohonan untuk keluar Islam atau murtad. ${ }^{16}$ Namun terdapat beberapa negeri yang mempunyai peruntukan undang-undang berkaitan dengan permohonan keluar Islam dalam pelbagai enakmen undangundang syariah negeri-negeri kecuali negeri Kelantan, Perlis, Sarawak, Pahang dan Wilayah Persekutuan. ${ }^{17}$

\section{UNDANG-UNDANG BERKAITAN PERMOHONAN KELUAR ISLAM DI MALAYSIA}

Terdapat sekurang-kurangnya tiga bentuk peruntukan yang berkaitan dengan permohonan untuk keluar Islam. Tiga bentuk peruntukan tersebut ialah;

a) Memohon keluar Islam adalah kesalahan jenayah Syariah dan boleh didakwa di Mahkamah Syariah atas pelbagai kesalahan seperti kesalahan

14 Salleh Buang, Siri Perkembangan Undang-Undang di Malaysia, Perlembagaan dan Pentadbiran, Isu Kritikal, 12.

15 Salleh Buang, Siri Perkembangan Undang-Undang di Malaysia, Perlembagaan dan Pentadbiran, Isu Kritikal, 13.

16 SUHAKAM, 'The Rights of Conversion and It's Effect in Relation to Human Rights,' Malaysian Journal on Human Rights 4 (Julai 2008): 40-41.

17 Dalam perkembangan terkini, hanya negeri Sarawak, Kelantan, Wilayah Persekutuan dan Pahang yang tidak mempunyai sebarang peruntukan untuk mengurus kes Permohonan Keluar Islam. Namun seksyen 124 Enakmen Majlis Agama Islam dan Adat Istiadat Kelantan 1994 memperuntukkan bahawa: "membantu orang Islam keluar dari agama Islam adalah satu kesalahan dan boleh dihukum denda tidak melebihi RM 5,000.00 atau penjara tidak melebihi 3 (tiga) tahun atau kedua-duanya sekali." 
percubaan murtad, ${ }^{18}$ menghina agama, ${ }^{19}$ murtad untuk mengelakkan tindakan pihak berkuasa agama ${ }^{20}$ atau melakukan perbuatan atau perkataan murtad..$^{21}$ Hanya terdapat dua jenis kesalahan diperuntukan dalam Enakmen Kesalahan Jenayah Syariah (Sabah) 1995 iaitu kesalahan percubaan murtad (seksyen 63) ${ }^{22}$ dan kesalahan menghina Islam (seksyen 55(2)). ${ }^{23}$

Setakat kajian ini dijalankan, belum terdapat satu kes pun yang didakwa di bawah kesalahan percubaan murtad walaupun Sabah telah dilaporkan menerima banyak kes permohonan keluar Islam. Manakala bagi kesalahan menghina agama Islam, hanya terdapat satu kes dan tertuduh telah disabitkan atas pengakuan salahnya di Mahkamah Rendah Syariah Kudat. Oleh sebab itu, sejauh mana kedua-dua peruntukan ini berkesan dalam menangani masalah murtad dalam kalangan orang Islam masih belum diketahui. Walaupun ada pihak yang berpandangan peruntukan ini tidak berperlembagaan kerana bertentangan dengan Perkara 5 (1) dengan mengadakan pemulihan secara paksa, ${ }^{24}$ ada juga pihak lain yang berpandangan bahawa peruntukan ini dibuat dalam kerangka Jadual

18 Seksyen 66 Enakmen Kesalahan Jenayah Syariah (Melaka) 1991 (No. 6 Tahun 1991) dan Seksyen 63 Ekamen Kesalahan Jenayah Syariah (Sabah) 1995 (No. Tahun 1995)

19 Seksyen 55(2) Enakmen Kesalahan Jenayah Syariah (Sabah) 1995 dan seksyen 63(2) Enakmen Kesalahan Jenayah Syariah (Melaka) 1991.

20 Seksyen 7 Enakmen Kesalahan Jenayah Syariah (Ta'zir) (Negeri Terangganu) 2001 (No. 7 Tahun 2001), seksyen 12 Enakmen Jenayah Syariah (Perak) 1992 (No. 3 Tahun 1992) dan seksyen 48 Enakmen Jenayah Syariah (Negeri Sembilan) 1992 (No. 4 Tahun 1992).

21 Seksyen 13 Enakmen Jenayah (Syariah) (Perak).

22 Seksyen 63 EKJS 1995 telah memperuntukkan kesalahan percubaan murtad yang membawa kepada hukuman pemulihan akidah ataupun istitābah selama tidak lebih 36 bulan di pusat tahanan akidah yang diwartakan. Sekiranya dalam tempoh 36 bulan tersebut, tertuduh enggan untuk bertaubat, maka Mahkamah Syariah boleh memanjangkan tempoh tahanan tersebut untuk tempoh 36 bulan lagi sehinggalah tertuduh bertaubat. Tiada sebarang penalti diperuntukkan bagi kesalahan ini.

23 Bagi kesalahan menghina Islam pula di bawah seksyen 55 (2) EKJS 1995, perbuatan membuat pernyataan bahawa seseorang itu bukan Islam dengan apa cara sekalipun adalah bersalah kerana telah menghina Islam dan boleh dihukum dengan denda tidak melebihi RM1,000.00 atau pemenjaraan tidak lebih enam bulan atau kedua-duanya sekali. Seksyen ini pari materia dengan peruntukan seksyen 63 (2) Enakmen Kesalahan Jenayah Syariah (Melaka) 1991. Namun seksyen ini memperuntukkan hukuman maksimum iaitu denda tidak melebihi RM5,000.00 atau pemenjaraan tidak melebihi tiga tahun atau kedua-duanya sekali.

24 Shad Saleem Faruqi, Document of Destiny, the Constitution of the Federation of Malaysia, 346. 
Sembilan Senarai Dua Butiran Satu yang membenarkan kerajaan negeri menggubal undang-undang untuk mengawal akidah orang-orang Islam. ${ }^{25}$

b) Permohonan keluar Islam boleh difailkan di Mahkamah Tinggi Syariah di bawah premis pengesahan status agama bagi orang yang masih hidup. Antara negeri yang mempunyai peruntukan ini ialah Negeri Selangor, Pulau Pinang, Kedah dan Johor. Namun bagi negeri-negeri yang tidak mempunyai peruntukan ini, kes permohonan keluar Islam atau pengesahan status agama didengar di Mahkamah Tinggi Syariah melalui bidang kuasa secara implikasi atas kefahaman bahawa sekiranya Mahkamah Syariah diberikan bidangkuasa untuk memutuskan status agama orang yang telah mati, maka Mahkamah Syariah juga boleh memutuskan status agama orang yang masih hidup. Pendekatan ini dilaksanakan di Negeri Sabah dan Wilayah Persekutuan.

c) Peruntukan berkenaan proses runding cara akidah di pusat pemulihan akidah. Hanya Negeri Sembilan yang mempunyai peruntukan ini di bawah seksyen 119 Enakmen Pentadbiran Agama Islam (Negeri Sembilan) 2003. ${ }^{26}$

\section{PENGATURAN KES PERMOHONAN KELUAR ISLAM DI MALAYSIA}

Lee Min Choo, menjelaskan terdapat lima kaedah yang sering digunakan untuk keluar dari agama Islam iaitu; ${ }^{27}$

a) Melalui ikrar pemohon dalam Akaun Sumpah (Statutory Declaration),

b) Membuat permohonan untuk menukar nama di Jabatan Pendaftaran Negara (JPN),

c) Mempraktikkan agama baru mereka,

d) Membuat laporan kepada Jabatan Agama Negeri,

e) Mendapatkan deklarasi atau pengesahan bahawa pemohon bukan seorang Islam atau telah keluar Islam.

25 Abdul Aziz Bari, Islam dalam Perlembagaan Persekutuan (Petaling Jaya: Intel Media and Publications, 2005), 113-133.

26 Mohamad Zamri Mohamed Shapik, 'Peruntukan Undang-Undang Murtad di Selangor: Satu Kajian Berasaskan Maqasid Syariah’ (Disertasi Sarjana Syariah Universiti Malaya, 2011). Berdasarkan kajian beliau, runding cara akidah juga dilaksanakan di Selangor, namun, perlaksanaan runding cara akidah tersebut dibuat hanyalah secara pentadbiran sahaja tanpa ada apa-apa peruntukkan undang-undang yang membolehkan MAIS menahan mana-mana orang untuk tujuan tersebut.

27 Lee Min Choo, Freedom of Religion in Malaysia (Petaling Jaya: KAIROS Publication, 1999), 55. 
Antara kelima-lima kaedah tersebut, beliau menyatakan kaedah kelima adalah kaedah yang relevan memandangkan agensi kerajaan terutamanya JPN hanya mengiktiraf pengesahan yang dikeluarkan oleh Mahkamah. ${ }^{28}$ Oleh sebab itu, empat kaedah yang lain sudah tidak relevan dalam mana-mana urusan rasmi kerajaan untuk menyatakan bahawa pemohon bukan lagi beragama Islam. Selepas kes Soon Singh Bikar Singh lwn. PERKIM Kedah diputuskan pada tahun 1999, ${ }^{29}$ isu Mahkamah Syariah sebagai convenience forum bagi kes-kes yang berkaitan dengan permohonan keluar Islam telah pun menjadi akademik. $^{30}$

Namun begitu, untuk mendapatkan perintah atau deklarasi dari Mahkamah Syariah bahawa seseorang itu bukan atau bukan lagi beragama Islam bukanlah satu perkara yang mudah. Inikerana perbuatan keluar Islam ataupun permohonan supaya diisytiharkan sebagai bukan Islam adalah satu kesalahan riddah, perbuatan yang amat dilarang dalam Islam, berdosa besar dan hukumannya amat berat mengikut majoriti fuqaha. ${ }^{31}$ Isu permohonan keluar Islam ini juga dikaitkan dengan kebebasan beragama seperti yang telah diperuntukan dalam Perkara 11 Perlembagaan Persekutuan. ${ }^{32}$ Oleh sebab itu, bukanlah suatu yang menghairankan sekiranya sebelum Mahkamah Sivil memberikan bidang kuasa kepada Mahkamah Syariah untuk membicarakan dalam perkara yang berkaitan dengan permohonan keluar Islam secara implikasi, telah berlaku insiden 'tarik tali' di antara Mahkamah Sivil dan Mahkamah Syariah. ${ }^{33}$

Refleksi daripada kepelbagaian pendekatan undang-undang mengenai permohonan keluar Islam seperti yang telah dibincangkan sebelum ini telah menyebabkan terdapat sekurang-kurangnya tiga bentuk kaedah yang diambil oleh negeri-negeri dalam menggendalikan kes permohonan keluar Islam, iaitu;

28 Lee Min Choo, Freedom of Religion in Malaysia (Petaling Jaya: KAIROS Publication, 1999), 55.

29 Kes Soon Singh Bikar Singh lwn. PERKIM Kedah [1999] 1 MLJ 489.

30 Siti Zubaidah Ismail, 'Pertindihan Bidang Kuasa Mahkamah Syariah: Sorotan Terhadap Kes-kes Murtad,' Jurnal Undang-Undang IKIM 4/2 (Julai-Disember 2000): 67.

31 Haji Said Haji Ibrahim, Jinayah Murtad dari Sudut Syara'dan Perundangan Islam (Kuala Lumpur: Darul Ma'rifah, 1998), 71-79.

32 Shad Saleem Faruqi, Document of Destiny, the Constitution of the Federation of Malaysia, 345.

33 Siti Zubaidah Ismail, 'Pertindihan Bidang Kuasa Mahkamah Syariah: Sorotan Terhadap Kes-kes Murtad,', 67. 
a) Permohonan keluar agama Islam difailkan terus ke Mahkamah Tinggi Syariah yang berbidang kuasa menentukan status agama seseorang;

b) Permohonan keluar Islam difailkan ke Mahkamah Tinggi Syariah dan permohonan berkenaan ditangguhkan dan dirujuk kepada sebuah Jawatankuasa Khas untuk proses istitābah atau runding cara akidah;

c) Permohonan dipohon di Jabatan agama tanpa merujuk ke Mahkamah Syariah.

\section{a) Permohonan keluar agama Islam difailkan ke Mahkamah Tinggi Syariah yang berbidang kuasa menentukan status agama seseorang}

Bagi bentuk pengaturan yang pertama, pengesahan bukan Islam atau telah keluar Islam boleh diberikan oleh Mahkamah Syariah tanpa melalui satu jawatankuasa khas seperti di Selangor dan Negeri Sembilan. Sabah adalah antara negeri yang mempunyai pengurusan sebegini. Berdasarkan kajian yang dijalankan oleh Amir Husin Mohd Nor dan kumpulannya dari Universiti Kebangsaan Malaysia, belum ada prosedur yang jelas bagaimana kes permohonan keluar Islam diselanggarakan di Sabah. ${ }^{34}$ Oleh kerana itu, semua kes tersebut terus difailkan ke Mahkamah Syariah. Dalam menguruskan kes tersebut, Jabatan Kehakiman Syariah Negeri Sabah telah menjalinkan kerjasama dengan Jabatan Hal Ehwal Agama Islam Negeri Sabah (JHEAINS) dengan menamakan Pendaftar Mualaf JHEAINS sebagai Responden. ${ }^{35}$

Dilema bagi negeri Sabah dan Wilayah Persekutuan ialah berkenaan tiadanya punca kuasa Mahkamah Syariah untuk mendengar kes Permohonan Keluar Islam ini. Ini kerana Enakmen Mahkamah Syariah (Sabah) 2004 dan Akta Pentadbiran Undang-Undang Islam (Wilayah-Wilayah Persekutuan) 1993 hanya mempunyai peruntukan berkenaan pengesahan status agama bagi orang yang telah mati. Oleh sebab itu, bagi Wilayah Persekutuan, kes sedemikian telah didengar melalui kaedah implikasi seperti mana kaedah yang digunapakai oleh Mahkamah Awam dalam memberikan bidang kuasa tersebut kepada Mahkamah Syariah. Kaedah ini telah diakrukan dalam kes Balbir Abdullah lwn. Pendaftar Muallaf Majlis Agama Islam Wilayah Persekutuan ${ }^{36}$ dan juga

34 Amir Husin Mohd Nor, Amir Fazlim Yusoff, Muhammad Nazir Alias, Kesalahan Jenayah Aqidah Menurut Kerangka Perundangan di Malaysia (Bangi: Jabatan Syariah, Fakulti Pengajian Islam UKM, 2010), 142-143.

35 Amir Husin Mohd Nor, Amir Fazlim Yusoff, Muhammad Nazir Alias, Kesalahan Jenayah Aqidah Menurut Kerangka Perundangan di Malaysia, 142.

36 Kes Balbir Abdullah lwn. Pendaftar Muallaf Majlis Agama Islam Wilayah Persekutuan [2009] 1 CLJ (Sya), 365-383. 
kes Sumanthi A/P Maniam lwn. Majlis Agama Islam Wilayah Persekutuan. ${ }^{37}$ Pendekatan ini telah diikuti oleh Mahkamah Syariah di Sabah.

Bagi negeri yang membenarkan permohonan tersebut difailkan di Mahkamah Syariah, semua kes tersebut akan difailkan melalui SPKMS. Bagi tujuan pengurusan kes di Mahkamah Syariah, semua kes yang difailkan akan diberikan kod seperti yang telah dijelaskan sebelum ini. Bagi kes permohonan keluar Islam atau pengesahan status agama, kes tersebut akan diberikan kod 043 yang bertajuk "Permohonan Keluar Islam". Oleh kerana itu, apa juga kes yang didaftarkan di bawah kod 043 dalam SPKMS, kes tersebut akan dirujuk sebagai kes permohonan keluar Islam walaupun merit kes tersebut ialah pengesahan status agama ataupun pengesahan bukan Islam.

\section{b) Permohonan keluar Islam difailkan ke Mahkamah Tinggi Syariah dan permohonan berkenaan ditangguhkan dan dirujuk kepada sebuah Jawatankuasa Khas bagi mengendalikan proses taubat}

Bentuk pengaturan yang kedua ini boleh dirujuk kepada Enakmen Pentadbiran Agama Islam 2003 Negeri Sembilan. Seksyen 119 telah memperuntukkan runding cara akidah sebelum Mahkamah Syariah memutuskan sama ada pemohon masih lagi seorang Islam ataupun sebaliknya. ${ }^{38}$ Dalam kajian yang dibuat oleh Suria Halim, terdapat 29 permohonan keluar Islam dibenarkan di Negeri Sembilan daripada tahun 1994-2006 setelah melalui proses kaunseling yang dikendalikan oleh Pejabat Mufti. ${ }^{39}$ Prosedur keluar Islam di Negeri Sembilan telah dilihat sebagai model bagi membolehkan kes permohonan keluar Islam dikendalikan dengan lebih baik. Namun, disebabkan istilah yang digunakan oleh seksyen berkenaan iaitu Keluar Agama Islam, maka ia tidak begitu disukai oleh Mufti negeri-negeri lain yang berhasrat meniru peraturan di Negeri Sembilan.

Di negeri Selangor pula, proses kaunseling yang dijalankan lebih berbentuk pentadbiran. Ini kerana tiada undang-undang yang menyatakan bidang kuasa Mahkamah Syariah ataupun Jabatan Agama Islam Selangor (JAIS) untuk

37 Sumanthi A/P Maniam lwn. Majlis Agama Islam Wilayah Persekutuan [1434H]JH 36/1, 143-159

38 Pawancheck Marican dan Mohammed Azam Mohammed Adil, 'Apostasy and Freedom of Religion in Malaysia: Constitutional Implication,' Malaysian Journal of Human Rights 1 (June 2007): 96-98; Yusmarizza Md Yusuf dan Yuhanif Yusuf, 'Implikasi Kes Lina Joy: Satu Keperluan kepada Penyeragaman Prosedur Keluar Islam (Murtad) oleh Mahkamah Syariah,' KANUN 3 (2007): 33.

39 Suria Halim, 'Kes-kes Mengenai Pertukaran Agama Islam di Mahkamah Tinggi Syariah Negeri Sembilan' (Kertas Projek, Sarjana Muda Syariah Universiti Malaya, 2007), 35. 
mengadakan pusat tahanan, kaunseling dan proses istitābah kepada pemohon. Berdasarkan kajian Mohamad Zamri Mohamed Shapik, beliau menyimpulkan, pengurusan kes permohonan Islam di Selangor dijalankan secara kolektif. ${ }^{40}$ Ini kerana Mahkamah Syariah, Bahagian Undang-Undang Majlis Agama Islam Selangor (MAIS), Bahagian Pembangunan Iman MAIS, Bahagian Dakwah dan Bahagian Penyelidikan Jabatan Agama Islam Selagor (JAIS) disatukan gerak kerjanya di bawah "Jawatankuasa Penasihatan Akidah" yang dipengerusikan oleh Mufti Selangor. ${ }^{41}$

\section{c) Permohonan dibuat di Jabatan Agama tanpa merujuk ke Mahkamah Syariah}

Menurut Mohammed Azam Mohammed Adil, Sarawak adalah negeri yang mengambil pendekatan membuat permohonan di Jabatan Agama dan bukannya ke Mahkamah Syariah. ${ }^{42}$ Senario ini berlaku kerana Mahkamah Syariah di Sarawak enggan mendengar dan memutuskan kes permohonan keluar Islam yang menyebabkan pihak Kerajaan telah mengarahkan Jabatan Agama Negeri Sarawak memberikan pengesahan bukan Islam tersebut. Jabatan Agama Negeri Sarawak hanya akan mengeluarkan pengesahan tersebut setelah Pemohon melalui beberapa proses kaunseling. ${ }^{43}$

Dari huraian di atas, dapatlah difahami bahawa ketidakselarasan undangundang dan pengaturan mengenai permohonan atau tindakan terhadap orang yang berhasrat menentukan status agama mereka atau ingin kelur dari Islam telah menjadikannya tidak bersifat nasional dan perlu difahami mengikut konteks negeri tersebut. Oleh yang demikian, dalam bahagian seterusnya, perbincangan akan memfokuskan kepada realiti di negeri Sabah.

\section{METODOLOGI KAJIAN}

Data utama dalam kajian ini ialah fail-fail kes permohonan keluar Islam yang telah difailkan dan selesai di Mahkamah Tinggi Syariah (MTS) di Sabah

40 Mohamad Zamri Mohamed Shapik, 'Peruntukan Undang-Undang Murtad di Selangor: Satu Kajian Berasaskan Maqasid Syariah,’ 40.

41 Mohamad Zamri Mohamed Shapik, 'Peruntukan Undang-Undang Murtad di Selangor: Satu Kajian Berasaskan Maqasid Syariah,’ 42.

42 Mohammed Azam Mohammed Adil, 'Law of Apostasy and Freedom of Religion in Malaysia,' 2 Asian Journal of Comparative Law (2007): 159.

43 Mohammed Azam Mohammed Adil, 'Law of Apostasy and Freedom of Religion in Malaysia,' 159. 
khususnya di MTS Kota Kinabalu dan MTS Keningau. Ini kerana semasa kajian ini dijalankan (dari 2009 hingga 2011), hanya dua MTS ini sahaja yang mempunyai banyak kes berdasarkan kepada statistik Pejabat Ketua Pendaftar Jabatan Kehakiman Syariah Negeri Sabah (JKSNS). Berdasarkan kepada statistik tersebut, hanya dua atau tiga kes sahaja yang didaftarkan di MTS Tawau dan MTS Sandakan manakala tiada kes yang difailkan di MTS Kudat. Oleh kerana itu, tindakan untuk mendapatkan dan mengkaji fail-fail tersebut di Sandakan, Tawau dan Kudat adalah tidak ekonomik. ${ }^{44}$ Sebanyak 118 kes permohonan keluar Islam dan kes pengesahan bukan Islam yang telah didaftarkan dalam SPKMS di bawah kod 043 dan telah selesai dipilih untuk dikaji. Selain daripada fail kes, dokumen lain yang turut dikaji ialah arahan-arahan pentadbiran dan borang-borang yang berkaitan di Mahkamah Syariah, JHEAINS dan JPN. Selain daripada kajian fail kes tersebut, data juga diperolehi melalui temu bual separa berstruktur dan pemerhatian.

\section{DAPATAN KAJIAN: PROFIL KES PERMOHONAN KELUAR ISLAM DI MAHKAMAH SYARIAH SABAH}

Jadual 1 menunjukkan statistik kes permohonan keluar Islam yang difailkan di Mahkamah Syariah di seluruh Sabah dari tahun 2000-2010. Berdasarkan statistik tersebut, sebanyak 245 kes permohonan kes telah didaftarkan untuk tempoh tersebut. MTS Kota Kinabalu telah mencatatkan jumlah terbesar dengan 236 kes yang didaftarkan dan diikuti oleh MTS Keningau dengan lapan kes. Satu kes telah didaftarkan di MTS Sandakan manakala tiada kes didaftarkan di MTS Kudat dan MTS Tawau. ${ }^{45}$

\footnotetext{
44 Berdasarkan kepada maklumat yang diterima daripada kakitangan JHEAINS di Tawau dan Sandakan kes-kes tersebut melibatkan kesilapan JPN dalam meletakkan status agama pemohon.

45 Terdapat lima buah Mahkamah Tinggi Syariah (MTS) di Sabah yang iaitu MTS Kota Kinabalu, MTS Keningau, MTS Kudat, MTS Sandakan dan MTS Tawau. Berdasarkan Jadual 1, Penulis hanya menjalankan kajian kes di MTS Kota Kinabalu dan MTS Keningau kerana MTS Tawau, MTS Sandakan dan MTS Kudat hanya menerima satu kes sahaja atau tiada.
} 
Jadual 1 : Statistik Kes Permohonan Keluar Islam yang Difailkan di Mahkamah Syariah di Sabah dari Tahun 2000-2010.

\begin{tabular}{lccc}
\hline \multicolumn{1}{c}{ Mahkamah } & Kes Daftar & Kes Selesai & Baki \\
\hline MTS Kota Kinabalu* & 236 & 137 & 99 \\
MTS Sandakan & 1 & - & 1 \\
MTS Kudat & - & - & - \\
MTS Keningau** & 8 & 8 & - \\
MTS Tawau & - & - & - \\
\hline \multicolumn{1}{c}{ Jumlah } & $\mathbf{2 4 5}$ & $\mathbf{1 4 5}$ & $\mathbf{1 0 0}$ \\
\hline
\end{tabular}

Sumber: Jabatan Kehakiman Syariah Negeri Sabah.

\section{Bangsa}

Jadual 2 pula menunjukkan taburan kes mengikut bangsa pemohon berdasarkan 118 sampel kes yang telah dikaji. Didapati 98 kes telah difailkan oleh Bumiputera Sabah ${ }^{46}$ yang majoritinya berbangsa Dusun (58) dan Kadazan (18). Manakala hanya 19 kes atau 16.1 Peratus difailkan oleh pemohon berbangsa Cina dan seorang oleh pemohon yang dari Indonesia dan tiada kes yang difailkan oleh pemohon berbangsa Melayu.

$46 \quad$ Dalam Ordinan Tafsiran (Anak Negeri) 1952, Bumiputera Sabah lebih dikenali sebagai "Anak Negeri" (Native) dan bukannya bumiputera. Oleh kerana itu, Mahkamah Adat di Sabah lebih dikenali dengan nama Mahkamah Anak Negeri dan bukanlah Mahkamah Bumiputera.

* MTS Kota Kinabalu hanya menerima kes permohonan keluar Islam bermula tahun 2004. Taufik Ali (Timbalan Pendaftar, Mahkamah Tinggi Syariah Kota Kinabalu), dalam temu bual dengan penulis, pada 21 Julai 2011. Manakala MTS Keningau mula menerima kes Permohonan Keluar Islam pada tahun 2003; Ishak Tuah (Penolong Syariah, Mahkamah Syariah Keningau), dalam temu bual dengan penulis pada 22 Julai 2011.

** Berdasarkan penelitian pengkaji terhadap 'Buku Rekod Pendaftaran Kes' di MTS Keningau, terdapat 32 permohonan keluar Islam kes yang difailkan di bawah kod 043. Menurut Taherah Tahir, memang akan terdapat perbezaan rekod dalam SPKMS dan rekod manual. Taherah Tahir (Pendaftar, Mahkamah Tinggi Syariah Kota Kinabalu), dalam temu bual dengan penulis, pada 21 Julai 2011. 
Jadual 2: Taburan Pemohon Mengikut Bangsa.

\begin{tabular}{lcc}
\hline \multicolumn{1}{c}{ Bangsa } & Jumlah & Peratus \\
\hline Dusun & 58 & $49.2 \%$ \\
Cina & 19 & $16.1 \%$ \\
Kadazan & 18 & $15.3 \%$ \\
Murut & 9 & $7.7 \%$ \\
Suluk & 4 & $3.8 \%$ \\
Rungus & 4 & $3.8 \%$ \\
Sungai & 2 & $1.7 \%$ \\
Bisaya & 1 & $0.8 \%$ \\
Indonesia & 1 & $0.8 \%$ \\
Iban & 1 & $0.8 \%$ \\
\hline \multicolumn{1}{c}{ Jumlah } & $\mathbf{1 1 8}$ & $\mathbf{1 0 0} \%$ \\
\hline
\end{tabular}

Sumber: Sampel Kes.

\section{Umur Pemohon}

Dalam Jadual 3, umur pemohon adalah merujuk kepada umur pemohon semasa permohonan ini difailkan di Mahkamah Syariah. Merujuk kepada Jadual 3, 86 kes telah difailkan oleh pemohon yang berusia 19 hingga 39 tahun. Manakala empat kes difailkan oleh pemohon yang berusia 18 dan ke bawah dan selebihnya ialah pemohon yang berusia 40 hingga 79 tahun. Berdasarkan kepada dapatan ini, 115 pemohon telah mencapai umur dewasa. ${ }^{47}$

Jadual : 3 Taburan Pemohon Mengikut Umur.

\begin{tabular}{ccc}
\hline Umur & Bilangan Kes & Peratus \\
\hline 18 tahun ke bawah & 4 & $3.4 \%$ \\
19 tahun -29 tahun & 42 & $36 \%$ \\
30 tahun -39 tahun & 44 & $37.3 \%$ \\
40 tahun -49 tahun & 13 & $11.0 \%$ \\
50 tahun -59 tahun & 9 & $8 \%$ \\
60 tahun -69 tahun & 3 & $2.5 \%$ \\
70 tahun -79 tahun & 2 & $1.7 \%$ \\
\hline Jumlah & $\mathbf{1 1 8}$ & $\mathbf{1 0 0} \%$ \\
\hline
\end{tabular}

Sumber: Sampel Kes.

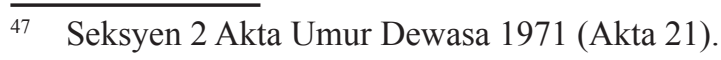




\section{Status Agama Pemohon dan Faktor Permohonan}

Jadual 4 menunjukkan pecahan pemohon mengikut status agama mereka semasa memfailkan kes permohonan keluar Islam di Mahkamah Syariah di Sabah. ${ }^{48}$

Jadual 4 : Taburan Kes Mengikut Status Agama Pemohon.

\begin{tabular}{|c|c|c|}
\hline Status agama & Kes & Peratus \\
\hline Bukan Islam & 52 & $44.1 \%$ \\
\hline Status agama belum ditentukan & 20 & $16.9 \%$ \\
\hline Islam secara pemelukan di JHEAINS & 18 & $15.3 \%$ \\
\hline Islam asal & 16 & $13.5 \%$ \\
\hline Islam secara pemelukan beramai-ramai & 12 & $10.2 \%$ \\
\hline Jumlah & 118 & $100 \%$ \\
\hline
\end{tabular}

Sumber: Sampel Kes.

Berdasarkan jadual status agama di atas, pemohon boleh dibahagikan kepada lima kumpulan utama. Lima kumpulan tersebut ialah;

a) Pemohon yang bukan beragama Islam, namun dalam MyKad mereka tertera perkataan Islam,

b) Pemohon yang belum ditentukan status agamanya,

c) Pemohon yang memeluk Islam di Jabatan agama iaitu golongan muallaf,

d) Pemohon yang memeluk Islam secara beramai-ramai pada pertengahan tahun 1970-an hinggalah pertengahan tahun 1980-an,

e) Pemohon yang beragama Islam asal.

\section{a) Pemohon yang Bukan Beragama Islam}

Pemohon bukan Islam merujuk kepada pemohon yang tidak mempunyai latar belakang sebagai penganut agama Islam sama ada secara keturunan ataupun melalui pemelukan Islam. Kumpulan ini telah memfailkan permohonan keluar Islam di Mahkamah Syariah bagi membolehkan mereka meminda status agama Islam dalam MyKad mereka. Keadaan ini berlaku kerana terdapat kekeliruan di JPN rentetan daripada kecenderungan masyarakat Bumiputera bukan Islam di Sabah menggunakan nama lazim bagi orang Islam dan juga menggunakan 'bin' dan 'binti'.

48 Penulis menilai status agama Pemohon berdasarkan Afidavit Sokongan Pemohon, surat beranak dan nota prosiding yang terdapat di dalam fail kes di Mahkamah. 
Berdasarkan sampel kes yang telah dipilih, kes kesilapan di JPN bukanlah kes yang terpencil di Sabah. Ini kerana 52 kes atau 44.1 peratus kes telah difailkan oleh kumpulan ini. Senarai pemohon mengikut bangsa yang dimaksudkan boleh dirujuk dalam Jadual 5. Berdasarkan Jadual 5 didapati sejumlah 31 kes telah diluluskan manakala 14 kes ditolak dan 7 kes ditutup oleh Mahkamah Syariah. ${ }^{49}$

Jadual 5 : Status Agama Pemohon Bukan Beragama Islam Mengikut Bangsa.

\begin{tabular}{lccc}
\hline \multicolumn{1}{c}{ Agama Sebenar } & Jumlah Kes & Diluluskan & Ditolak \\
\hline Kristian Dusun & 31 & 20 & 11 \\
Kristian Kadazan & 5 & 4 & 1 \\
Kristian Cina & 5 & 2 & 3 \\
Kristian Rungus & 4 & 4 & - \\
Kristian Iban & 1 & - & 1 \\
Kristian Murut & 2 & - & 2 \\
Kristian Indonesia & 1 & - & 1 \\
Budhha & 2 & 1 & 1 \\
Pagan & 1 & - & 1 \\
\hline \multicolumn{1}{c}{ Jumlah } & $\mathbf{5 2}$ & $\mathbf{3 1}$ & $\mathbf{2 1}$ \\
\hline
\end{tabular}

Sumber: Sampel Kes.

Senario kesilapan JPN meletakkan status agama Islam kepada pemohon yang bukan beragama Islam Islam boleh dilihat dalam beberapa kes berikut. Dalam kes Soliah Kambiris, ${ }^{50}$ pemohon seorang perempuan berbangsa Dusun telah memfailkan permohonan pengesahan bukan Islam kerana ingin meminda status agama dalam MyKadnya. Pemohon menyatakan bahawa dia dan ibu bapanya bukan beragama Islam. Namun demikian, ketika pemohon menukar "kad pengenalan bunga raya" kepada MyKad dan status agamanya ialah Islam. Berdasarkan Laporan Pendaftar Muallaf yang telah difailkan pada 28 November 2007, menyatakan pemohon dan kedua-dua ibu bapanya tidak pernah memeluk Islam. Permohonan pemohon telah diluluskan kerana pemohon bukanlah seorang Islam berdasarkan seksyen 2 EMUIS 2004.

\footnotetext{
49 Kes yang "ditutup" adalah kes yang ditolak tanpa merit kerana kegagalan Pemohon hadir ke Mahkamah ataupun masalah teknikal yang telah mencacatkan prosiding.

50 Kes Soliah Kambiris (MTS Kota Kinabalu) no. kes: 12100-043-0216-2009.
} 


\section{b) Pemohon yang Belum Ditentukan Status Agamanya}

Pemohon yang belum ditentukan status agama pula merujuk kepada pemohon yang tidak mempunyai status agama yang jelas, sama ada kerana salah seorang ibu bapa mereka bukan beragama Islam ataupun ibu bapa mereka memeluk Islam ketika mereka masih lagi kanak-kanak. Memandangkan salah seorang ibu bapa mereka beragama Islam, status agama mereka di JPN adalah Islam. Bagi kes begini, status agama mereka akan ditentukan oleh Mahkamah Syariah. Bagi memudahkan huraian perkara ini, kumpulan ini boleh dibahagikan kepada dua, iaitu;

i. Kumpulan Pertama: Pemohon mempunyai seorang sahaja daripada ibu bapanya yang beragama Islam. Keadaan ini berlaku kerana ibu atau bapa mereka berkahwin melalui perkahwinan adat bukan Islam dengan pasangan yang tidak beragama Islam. ${ }^{51}$ Terdapat 10 kes yang melibatkan pemohon dari kumpulan ini seperti yang dipaparkan dalam Jadual 6.

Jadual 6: Senarai Pemohon yang Belum Ditentukan

Status Agama (Kumpulan 1).

\begin{tabular}{ccccc}
\hline Bil. & $\begin{array}{c}\text { Nama Pemohon dan } \\
\text { Nombor Kes }\end{array}$ & $\begin{array}{c}\text { Agama } \\
\text { Ibu }\end{array}$ & $\begin{array}{c}\text { Agama } \\
\text { Bapa }\end{array}$ & Keputusan \\
\hline 1. & $12100-043-0394-2008$ & Pagan & Islam & Diluluskan \\
2. & $12100-043-0502-2009$ & Islam & Kristian & Ditolak \\
3. & $12100-043-0199-2009$ & Islam & Kristian & Diluluskan \\
4. & $12100-043-0271-2010$ & Kristian & Islam & Ditolak \\
5. & $12100-043-0515-2009$ & Pagan & Islam & Ditolak \\
6. & $12100-043-0562-2009$ & Kristian & Islam & Diluluskan \\
7. & $12200-043-0079-2004$ & Kristian & Islam & Ditolak \\
8. & $12100-043-0335-2008$ & Islam & Kristian & Ditolak \\
9. & $12200-043-0136-2004$ & Islam & Budha & Ditolak \\
10 & $12100-043-0031-2008$ & Budha & Islam & Ditolak \\
\hline
\end{tabular}

Sumber: Sampel Kes.

51 Perkahwinan adat dalam kajian ini merujuk kepada perkahwinan adat pribumi Sabah sama ada yang didaftarkan di Mahkamah Anak Negeri ataupun tidak. 
ii. Kumpulan Kedua: Pemohon yang 'terbawa memeluk Islam' kerana pemelukan Islam ibu bapa pemohon. ${ }^{52}$ Terdapat kes dalam kumpulan ini dan ia boleh dirujuk kepada Jadual 7.

Jadual 7: Senarai Pemohon yang Belum Ditentukan

Status Agama (Kumpulan 2).

\begin{tabular}{ccccc}
\hline Bil. & Nombor Kes & $\begin{array}{c}\text { Pihak yang } \\
\text { memeluk } \\
\text { Islam }\end{array}$ & $\begin{array}{c}\text { Umur Pemohon } \\
\text { Ketika Ibu/Bapa } \\
\text { memeluk Islam }\end{array}$ & Keputusan \\
\hline 1. & $12100-043-0543-2009$ & Ibu & 7 tahun & Ditolak \\
2. & $12100-043-0325-2009$ & Ibu & 1 tahun & Ditolak \\
3. & $12100-043-0253-2009$ & Bapa & 12 tahun & Ditolak \\
4. & $12100-043-0239-2009$ & Ibu bapa & 18 tahun & Diluluskan \\
5. & $12100-043-0271-2010$ & Bapa & 35 tahun & Diluluskan \\
6. & $12100-043-0152-2010$ & Bapa & 12 tahun & Ditolak \\
7. & $12100-043-0099-2009$ & Ibu bapa & Dalam kandungan & Ditolak \\
8. & $12100-043-0039-2008$ & Ibu bapa & 18 tahun & Ditutup \\
9. & $12100-043-0471-2008$ & Bapa & 7 tahun & Diluluskan \\
\hline
\end{tabular}

Sumber: Sampel Kes.

Berdasarkan Jadual 6 dan 7, sejumlah enam kes telah diluluskan kerana Mahkamah mendapati Pemohon bukanlah seorang Islam secara keturunan.

\section{c) Pemohon yang Beragama Islam Melalui Pemelukan Islam}

Berdasarkan kepada sampel kes, terdapat dua bentuk pemelukan Islam yang utama di Sabah, iaitu;

i. Pemelukan Islam secara beramai-ramai pada tahun pertengahan 1970-an hingga pertengahan 1980-an iaitu sebanyak $12 \mathrm{kes,}$

ii. Pemelukan Islam melalui prosedur biasa di JHEAINS.

Jadual 8 menunjukkan senarai kes yang difailkan oleh pemohon yang memeluk Islam secara beramai-ramai, manakala Jadual 9 menunjukkan

52 Terminologi 'terbawa memeluk Islam' adalah terminologi yang biasa digunakan oleh Hakim dalam merujuk seseorang yang dianggap sebagai Islam kerana pemelukan Islam ibu bapanya walaupun tanpa melalui proses pemelukan Islam seperti ibu bapanya; Jasri Mat Jakir (Yang Amat Arif, Ketua Hakim Jabatan Kehakiman Syariah Negeri Sabah), dalam temu bual dengan penulis, pada 21 Julai 2011. 
senarai pemohon yang memeluk Islam melalui prosedur pemelukan Islam biasa di JHEAINS. Berdasarkan Jadual 8, hanya tiga kes yang diluluskan, manakala lima kes telah ditolak dan empat kes lain telah di tutup. Manakala dalam Jadual 9 pula, sebanyak dua kes telah diluluskan, 11 kes telah ditolak dan lima kes lagi telah ditutup.

Jadual 8: Pecahan kes yang melibatkan pemohon yang telah memeluk Islam beramai-ramai berdasarkan dakwaan pemohon pemelukan Islam mereka tidak sah.

\begin{tabular}{|c|c|c|}
\hline Bil. & Dakwaan Pemohon & Jumlah \\
\hline 1. & $\begin{array}{l}\text { Pemohon tidak pernah melafazkan Dua Kalimah } \\
\text { Syahadah semasa upacara pemelukan Islam beramai- } \\
\text { ramai yang disertainya }\end{array}$ & 3 \\
\hline 2. & $\begin{array}{l}\text { Pemohon tidak tahu bahawa pemohon telah direkodkan } \\
\text { memeluk Islam }\end{array}$ & 4 \\
\hline 3. & $\begin{array}{l}\text { Kad Pengenalan pemohon telah diambil oleh penganjur } \\
\text { untuk direkodkan sebagai Islam sedangkan pemohon } \\
\text { tidak berada di dalam majlis pengislaman beramai-ramai } \\
\text { tersebut }\end{array}$ & 1 \\
\hline 4. & $\begin{array}{l}\text { Pemohon telah dijanjikan ganjaran oleh penganjur } \\
\text { sekiranya menyertai upacara pengislaman beramai-ramai } \\
\text { yang dianjurkan }\end{array}$ & 1 \\
\hline 5. & $\begin{array}{l}\text { Pemohon tidak mengetahui bahawa upacara pengislaman } \\
\text { beramai-ramai yang dihadirinya adalah upacara } \\
\text { pengislaman. }\end{array}$ & 3 \\
\hline \multicolumn{2}{|r|}{ Jumlah } & 12 \\
\hline
\end{tabular}

Sumber: Sampel Kes.

Jadual 9: Statistik Kes yang melibatkan pemohon yang memeluk Islam melalui prosedur biasa di JHEAINS dan agensi agama yang lain.

\begin{tabular}{|c|c|c|c|c|}
\hline \multirow{2}{*}{ Bil. } & \multirow{2}{*}{ Faktor Pemelukan Islam } & \multirow{2}{*}{ Jumlah } & \multicolumn{2}{|c|}{ Keputusan } \\
\hline & & & Lulus & Tolak \\
\hline 1. & $\begin{array}{l}\text { Berkahwin dengan pasangan } \\
\text { beragama Islam }\end{array}$ & 16 & 1 & 15 \\
\hline 2. & Sukarela & 2 & 1 & 1 \\
\hline & Jumlah & 18 & 2 & 16 \\
\hline
\end{tabular}

Sumber: Sampel Kes. 


\section{d) Pemohon Beragama Islam}

Kumpulan keempat ialah kumpulan pemohon yang dilahirkan oleh kedua ibu bapa yang beragama Islam. Kumpulan ini juga dikenali sebagai Islam asal (born Muslim). 16 kes telah difailkan oleh kumpulan ini. Jadual 10 menunjukkan senarai kes yang difailkan oleh pemohon dalam kumpulan ini.

Jadual 10: Pemohon Islam Asal (Ibu bapa beragama Islam).

\begin{tabular}{llcccc}
\hline Bil & $\begin{array}{c}\text { Bangsa } \\
\text { / suku }\end{array}$ & $\begin{array}{c}\text { Tidak pernah } \\
\text { diajar dan } \\
\text { mengamalkan } \\
\text { Islam }\end{array}$ & $\begin{array}{c}\text { Telah } \\
\text { berkahwin } \\
\text { dengan } \\
\text { pasangan } \\
\text { bukan Islam }\end{array}$ & $\begin{array}{c}\text { Dipelihara } \\
\text { oleh keluarga } \\
\text { angkat atau } \\
\text { ahli keluarga } \\
\text { bukan Islam }\end{array}$ & Jumlah \\
\hline 1. & Dusun & 3 & 4 & 1 & 8 \\
2. & Kadazan & 1 & - & 1 & 2 \\
3. & Suluk & - & 2 & - & 2 \\
4. & Sungai & - & - & 1 & 1 \\
5. & Murut & - & 3 & - & 3 \\
\hline & Jumlah & $\mathbf{4}$ & $\mathbf{9}$ & $\mathbf{3}$ & $\mathbf{1 6}$ \\
\hline
\end{tabular}

Sumber: Sampel Kes.

Melalui penelitian terhadap Jadual 10, kumpulan ini boleh dibahagikan kepada dua kategori ini iaitu pemohon yang dilahirkan dan dibesarkan oleh ibu bapa yang beragama Islam dan kedua pemohon yang dilahirkan oleh ibu bapa yang beragama Islam tetapi dibesarkan mengikut cara hidup bukan Islam. Bagi kumpulan ini, tiada permohonan yang diluluskan.

\section{ANALISIS}

Isu utama dalam pentadbiran kes permohonan keluar Islam di Mahkamah Syariah ialah isu pemakaian kod 043 di bawah tajuk "Permohonan Keluar Islam" dalam SPKMS. Pemakaian kod 043 inilah yang telah menyebabkan masyarakat telah diberi persepsi yang berbeza daripada realiti sebenar mengenai profil kes yang difailkan di Mahkamah Syariah di Sabah dan juga di negeri-negeri lain. Ini telah dibuktikan melalui dapatan kajian ini yang mana 84.8 peratus atau 100 kes daripada 118 kes yang telah dikaji sebenarnya telah difailkan dan diputuskan di bawah premis permohonan pengesahan status agama atau pengesahan bukan Islam dan bukannya permohonan untuk keluar dari agama Islam. 
Tindakan JKSNS memperkenalkan penggunaan kod 099 bagi kes permohonan pengesahan status agama adalah satu langkah proaktif bagi mengurangkan kes-kes yang didaftarkan di bawah kod 043. Namun pendekatan ini hanyalah bersifat sementara kerana pendekatan ini diambil bukanlah atas Arahan Amalan JKSM ataupun JKSNS tetapi hanyalah melalui arahan pentadbiran dalaman sahaja. Di samping itu pendekatan ini juga boleh menyebabkan pihak JKSNS sukar untuk mengenalpasti jumlah sebenar kes pengesahan status agama yang difailkan di Mahkamah Syariah melalui SPKMS kerana kes tersebut bercampur dengan kes-kes lain yang tidak mempunyai kod khusus. Oleh kerana itu, langkah ini bukanlah satu jalan penyelesaian bagi masalah ini dan satu kod khusus bagi kes pengesahan status agama perlu diwujudkan di dalam SPKMS.

Selain isu pemakaian kod 043, kajian ini mendapati pengurusan kes permohonan keluardi Sabah hanya merujuk kepada pengurusan kes permohonan keluar Islam yang ada di Mahkamah Syariah. Ini menunjukkan belum ada penyelarasan gerak kerja antara agensi-agensi kerajaan yang terlibat dalam mengendalikan kes permohonan keluar Islam. Setakat kajian ini dijalankan, prosedur runding cara akidah atau kaunseling dan proses istitābah belum lagi dilaksanakan walaupun peruntukan undang-undang mengenai sudah wujud sejak tahun 1995 lagi. ${ }^{53}$ Perkara ini berlaku kerana pusat pemulihan akidah ataupun Baitul Ehsan di Kinarut Sabah masih belum boleh digunakan. Ini telah menyebabkan proses runding cara akidah, istitäbah dan sebarang tindakan susulan yang lain tidak boleh dilaksanakan.

Dalam hal ini, pendekatan Negeri Selangor dalam mendepani masalah pentadbiran dalam pengurusan kes permohonan keluar Islam boleh dicontohi iaitu dengan menubuhkan satu jawatankuasa induk yang menyelaraskan gerak kerja agensi yang terlibat. Selain daripada itu, jawatankuasa ini boleh dijadikan forum untuk membincangkan apa-apa masalah berkaitan secara kolektif. Secara idealnya, masalah Baitul Ehsan dan apa juga masalah lain yang dihadapi boleh dibincangkan dan dicari jalan penyelesaiannya melalui Jawatan Kuasa Induk ini.

Dalam isu ketiadaan punca kuasa untuk memdengar dan membicarakan kes permohonan keluar Islam secara implikasi, ianya tidaklah menjejaskan pengurusan kes permohonan keluar Islam di Sabah. Ini kerana pendekatan yang sama juga telah digunakan di Mahkamah Syariah negeri lain. Namun pendekatan ini amat bergantung pada kesediaan Mahkamah Sivil menyerahkan bidang kuasa tersebut secara implikasi kepada Mahkamah Syariah. Dengan gerakan kebebasan hak asasi dan tekanan yang diberikan oleh NGO bukan Islam yang sentiasa mengkritik pendekatan yang diambil oleh Mahkamah

53 Seksyen 63, Enakmen Kesalahan Jenayah Syariah Negeri Sabah 1995. 
Awam yang telah memberikan bidang kuasa yang luas kepada Mahkamah Syariah, adalah wajar Mahkamah Syariah di Sabah diberikan bidang kuasa yang jelas seperti mana Negeri Selangor contohnya. Ini kerana pendekatan secara implikasi ini tidak akan releven lagi sekiranya Mahkamah Awam mengambil pendekatan merujuk kepada bidang kuasa eksklusif kelak.

Selain isu bidang kuasa, isu mode perbicaraan kes permohonan keluar Islam di Mahkamah Syariah Sabah juga relevan untuk dibincangkan berdasarkan pengalaman Mahkamah Syariah di Sabah dan juga profil kes yang unik berbanding dengan negeri-negeri lain di Semenanjung Malaysia. Sebelum September 2013, semua kes permohonan keluar Islam termasuklah kes pengesahan status agama dimulakan melalui Notis yang disokong dengan satu affidavit. Mode ini telah diamalkan di Mahkamah Syariah di Sabah sehingga ditegur oleh Mahkamah Rayuan Syariah Negeri Sabah bahawa kes permohonan keluar Islam atau pengesahan status agama bukanlah termasuk dalam kes yang boleh dimulakan dengan Permohonan seperti seksyen 7 ETMMSS 2014. Oleh sebab mode kes berkenaan telah ditukar kepada saman bermula awal tahun 2014.

Namun berdasarkan kepada profil kes yang diperolehi melalui kajian ini, mode secara afidavit adalah amat sesuai bagi membolehkan mahkamah mendapat maklumat daripada pihak JHEAINS, JPN dan agensi-agensi yang berkaitan berdasarkan kepada keperluan satu-satu kes. Sekiranya semua kes berkenaan didengar melalui saman, pihak-pihak dalam prosiding tersebut perlu mengemukakan saksi di dalam perbicaraan dan mahkamah adalah terikat dengan keterangan daripada pihak-pihak tersebut. Ini sudah pasti akan membuang masa mahkamah dan juga pihak-pihak sekiranya isu yang dibicarakan hanyalah melibatkan kesilapan pentadbiran oleh mana-mana agensi kerajaan. Oleh sebab itu, kes-kes berkaitan permohonan keluar Islam perlu dimasukkan ke dalam Jadual Dua tersebut bagi membolehkan kes berkenaan didengar dan diputuskan melalui mode permohonan.

\section{SARANAN DAN PENUTUP}

Profil kes permohonan keluar Islam di Mahkamah Syariah Sabah mestilah difahami dalam konteks lokal. Ini kerana kegagalan memahaminya akan menyebabkan masyarakat salah faham mengenainya dan seterusnya akan memberikan satu persepsi yang salah kepada umum bahawa "Mahkamah Syariah di Sabah paling banyak meluluskan permohonan keluar Islam". Kegagalan memahami realiti sebenar ini adalah disebabkan pemakaian kod 043 SPKMS yang bertajuk "Permohonan Keluar Islam". Ini telah menyebabkan, maklumat yang diperolehi daripada SPKMS menunjukkan semua kes 
permohonan keluar Islam yang difailkan di Mahkamah Syariah Negeri Sabah diputuskan di bawah premis permohonan keluar Islam walaupun pada realitinya kes tersebut telah diputuskan di bawah premis pengesahan status agama. Oleh kerana itu, pemahaman pihak pentadbiran Jabatan Kehakiman Syariah (JKSM) mengenai isu ini amat kritikal bagi membolehkan SPKMS diubahsuai dengan memperkenalkan satu kod khas bagi kes pengesahan status agama. Ini kerana merit bagi kes permohonan keluar Islam dan pengesahan status agama amatlah berbeza. Pendekatan yang diambil oleh Mahkamah Syariah Sabah dengan menggunakan kod 099 adalah pendekatan yang bersifat sementara.

Meskipun kajian ini telah menunjukkan kebanyakan kes permohonan keluar Islam di Mahkamah Syariah di Sabah sebenarnya difailkan dan diputuskan di bawah premis pengesahan status agama, ini bukanlah bermakna Mahkamah Syariah tidak berhadapan dengan masalah yang serius. Ini kerana isu penentuan status agama berdasarkan senario yang berlaku di Sabah, amat menuntut kebijaksanaan Mahkamah dan agensi-agensi lain yang terlibat dalam menentukan status agama Pemohon. Oleh sebab itu, isu kes permohonan keluar Islam di Mahkamah Syariah di Sabah perlu difahami secara lokal agar masyarakat umum tidak beranggapan kes yang diluluskan di Mahkamah Syariah Sabah telah diputuskan atas merit keluar Islam atau murtad.

\section{RUJUKAN}

Abdul Aziz Bari, Islam dalam Perlembagaan Persekutuan (Petaling Jaya: Intel Media and Publications, 2005).

Amir Husin Mohd Nor, Amir Fazlim Yusof, Muhammad Nazir Alias, Kesalahan Jenayah Aqidah Menurut Kerengka Perundangan di Malaysia (Bangi: Jabatan Syariah, Fakulti Pengajian Islam UKM, 2010).

Ann Wang Seng, Murtad Jangan Pandang Sebelah Mata (Kuala Lumpur: Mustread Sdn. Bhd., 2009).

Francis Loh Kok Wah, Old vs. New Politics in Malaysia, State and Society in Transition (Petaling Jaya: SRID, 2009).

Haji Said Haji Ibrahim, Jinayah Murtad dari Sudut Syara'dan Perundangan Islam (Kuala Lumpur: Darul Ma'rifah, 1998).

Lee Min Choon, Freedom of Religion in Malaysia (Petaling Jaya: KAIROS Publication, 1999).

MalaysiaKini, 'Jamil Khir: Permohonan Murtad 135 Orang Diluluskan,' laman sesawang MalaysiaKini, http://www.malaysiakini.com.news/166920, 14 Jun 2011. 
Mohammad Ridhuan Tee Abdullah, Cabaran Saudara Baharu di Malaysia (Kuala Lumpur: Utusan Publication \& Distributor Sdn. Bhd., 2012).

Mohammed Azam Mohammed Adil, 'Law of Apostasy and Freedom of Religion in Malaysia,' Asian Journal of Comparative Law, 2 (2007).

Mohamad Zamri Mohamed Shapik, 'Peruntukan Undang-Undang Murtad di Selangor: Satu Kajian Berasaskan Maqasid Syariah,' (Disertasi Sarjana Syariah, Universiti Malaya, 2011).

Muhidin Yusin, Islam di Sabah (Kuala Lumpur: Dewan Bahasa \& Pustaka, 1990).

Pawancheck Marican dan Mohammed Azam Mohammed Adil, 'Apostasy and Freedom of Religion in Malaysia: Constitutional Implication,' Malaysian Journal of Human Rights 1 (June 2007).

Salleh Buang, Siri Perkembangan Undang-Undang di Malaysia, Perlembagaan dan Pentadbiran, Isu Kritikal, jil. 2 (Kuala Lumpur: DBP, 2007).

Shad Saleem Faruqi, Document of Destiny, the Constitution of the Federation of Malaysia (Petaling Jaya: STAR Publication, 2008).

Siti Zubaidah Ismail, 'Pertindihan Bidang Kuasa Mahkamah Syariah: Sorotan Terhadap Kes-kes Murtad,' Jurnal Undang-Undang IKIM 4/2 (JulaiDisember, 2000).

SUHAKAM, 'The Rights of Conversion and It's Effect in Relation to Human Rights,' Malaysian Journal on Human Rights 4 (Julai, 2008).

Suria Halim, 'Kes-kes mengenai Pertukaran Agama Islam di Mahkamah Tinggi Syariah Negeri Sembilan,' (Kertas Projek Sarjana Muda Syariah Universiti Malaya, 2007).

Ward Mitcheal Cates (terj.), Panduan Amali Penyelidikan Pendidikan (Kuala Lumpur: Dewan Bahasa \& Pustaka, 1990).

Yusmarizza Md Yusof dan Yuhanif Yusuf, 'Implikasi Kes Lina Joy: Satu Keperluan kepada Penyeragaman Prosedur Keluar Islam (Murtad) oleh Mahkamah Syariah,' KANUN (2007).

\section{Statut}

Enakmen Majlis Ugama Islam Sabah 2004 (En. 5/04).

Enakmen Tatacara Mal Mahkamah Syariah (Sabah) 2004 (En. 10/04).

Enakmen Pentadbiran Agama Islam Negeri Sembilan 2003 (En. 10/03).

Enakmen Kesalahan Jenayah Syariah Sabah (1995) (En. 3/95).

Perlembagaan Persekutuan. 


\section{Kes}

Balbir Abdullah lwn. Pendaftar Muallaf Majlis Agama Islam Wilayah Persekutuan [2009] 1 CLJ (Sya).

Lim Yoke Khoon lwn. Pendaftar Muallaf, Majlis Agama Islam Selangor \& Yang Lain [2006] 4 CLJ.

Lina Joy lwn. Majlis Agama Islam Wilayah Persekutuan \& Yang Lain [2005] 4 CLJ.

Majlis Agama Islam Pulau Pinang lwn. Siti Fatimah Tan binti Abdullah [1430H] JH 27/2.

Permohonan Perisytiharan Status Agama Janisah binti Abd Rahim @ Bigul, JH XXII (1427) H.

Roslinda binti Pius lwn. Pendaftar Muallaf, Jabatan Hal Ehwal Agama Islam Negeri Sabah [2009] 1 CLJ (Sya).

Sia Kwee Hin lwn. JAIWP [1992] 2 CLJ.

Soliah binti Kabiris lwn. Pendaftar Muallaf JHEAINS (kes tidak dilaporkan).

Soon Singh Bikar Singh lwn. PERKIM Kedah [1999] 1 MLJ 489.

Sumanthi A/P Maniam lwn. Majlis Agama Islam Wilayah Persekutuan [1434] JH 36/1.

Zubeydah Shaik Mohd lwn. Kalaichelvan Alagapan \& Yang Lain [2003] 8 CLJ.

\section{Temu bual}

Ishak Tuah (Penolong Syariah, Mahkamah Syariah Keningau), dalam temu bual dengan penulis, pada 22 Julai 2011.

Jasri Mat Jakir (Yang Amat Arif, Ketua Hakim Jabatan Kehakiman Syariah Negeri Sabah), dalam temu bual dengan penulis, pada 21 Julai 2011.

Taherah Tahir (Pendaftar, Mahkamah Tinggi Syariah Kota Kinabalu), dalam temu bual dengan penulis, pada 21 Julai 2011.

Taufik Ali (Timbalan Pendaftar, Mahkamah Tinggi Syariah Kota Kinabalu), dalam temu bual dengan penulis, pada 21 Julai 2011. 
Jurnal Syariah, Jil. 23, Bil. 1 (2015) 53-78 